\title{
Effect of Feeding a Combination of Zinc, Manganese and Copper Methionine Chelates of Early Lactation High Producing Dairy Cow
}

\author{
Ghada Mostafa El Ashry ${ }^{1}$, Ayman Abdel Mohsen Hassan ${ }^{2 *}$, Soliman Mohamed Soliman ${ }^{1}$ \\ ${ }^{1}$ Regional Centre for Food Feed, Agriculture Research Centre, Ministry of Agriculture, Dokki, Egypt; ${ }^{2}$ Animal Production Research \\ Institute, Ministry of Agriculture, Dokki, Egypt. \\ Email: "ghadaashry@yahoo.com
}

Received May $4^{\text {th }}$, 2012; revised June $1^{\text {st }}$, 2012; accepted June $8^{\text {th }}, 2012$

\begin{abstract}
The objective of the study was to compare the effect of feeding mixed chelated minerals ( $\mathrm{Mn}, \mathrm{Cu}$ and $\mathrm{Zn}$ ) methionine on dairy cow productive performance and milk yield and its components. The trial was conducted with dairy cows across various stage of lactation. The experimental treatments include chelated minerals (15 mg Zn as Zn Met, $20 \mathrm{mg}$ $\mathrm{Mn}$ as $\mathrm{Mn}$ Met, $10 \mathrm{mg} \mathrm{Cu}$ as $\mathrm{Cu}$ Met). Inorganic mixture contains (15 mg $\mathrm{Zn}$ as $\mathrm{ZnSO}_{4}, 20 \mathrm{mg} \mathrm{Mn}$ as $\mathrm{MnSO}_{4}, 10 \mathrm{mg}$ $\mathrm{Cu}$ as $\mathrm{CuSO}_{4}$ ) in sulphate forms. The experiment was commenced in the dry period of cows, 6 weeks before calving, and after calving the first three months of lactation was taken into consideration. Milk samples were collected from each cow evening and morning for estimation of milk yield production. The inorganic metals caused a significant decline ( $\mathrm{P}$ $<0.05$ ) in digestibility coefficients, nutritive value, nitrogen utilization, cell wall constituents, total VFA's, rumen volume, microbial and nitrogen synthesis compared to the organic metals. The treated group (chelated minerals) improved the milk yield, and the milk fat percentage of animals across various stages of lactation as compared to inorganic minerals treated group of animals, and no significant differences were observed among groups concerning the entire blood constituent.
\end{abstract}

Keywords: Milk Yield; Chelated Minerals; Dairy Cows; Milk Production

\section{Introduction}

The benefits of supplementation organic trace minerals in dairy diets have been demonstrated in research and in the field. Traditionally inorganic forms of trace minerals rapidly dissociation in the rumen and are free to interact with antagonists, resulting in the loss of the trace minerals prior to absorption by the animal [1,2]. Chelated organic trace minerals are bound to organic ligands through coordinate covalent bonds. The bonds between the ligand and the mineral can prevent the minerals from interacting with antagonists and improve the bioavailability of the mineral $[2,3]$. The basic reason for the use of organic forms of trace minerals is the increased bioavailability of organic vs inorganic sources of the minerals.

In addition to vitamin, protein, and energy requirements, the dairy cows also needs certain trace elements including zinc, copper, and manganese, plus the microelements magnesium and potassium for lactation and reproduction concurrent with growth and maintenance of body tissues $[4,5]$. During periods of dietary mineral in-

\footnotetext{
${ }^{*}$ Corresponding author.
}

sufficiencies, essential minerals will be cannibalized from body tissues to support milk production, which ultimately affects the quality and quantity of milk as well as reproduction [6,7]. [8] Demonstrated that supplemental metal amino acid chelates (AACs) were more bioavailable than inorganic metal salts (IOMs) and resulted in improved reproductive performance. Thirty days before expected parturition they supplemented the feed of dairy cows with AACs and IOMs and continued supplementation into lactation until the animals in the study became pregnant with a second calf. Cows receiving the AAC supplement conceived 48 days earlier than heifers receiving the IOM supplement (90 days versus 138 days) $(\mathrm{p}<0.05)$ and experienced $45 \%$ less early embryonic mortality (EEM) $(\mathrm{p}<0.05)$ [8]. Other researchers have also reported that AAC supplementation enhanced reproductive performance, but their studies have tended to focus on multiparous cows $[9,10]$.

A few studies have been undertaken in sheep. Those of Spears [11,12] corroborated each other in that each found that absorption was essentially identical for inorganic and chelated zinc, being about $40 \%$, but that the chelated 
form of zinc was retained better $(p<0.05)$ than the inorganic form of zinc.

\section{Materials and Methods}

\subsection{Animal and Experimental Design}

Twenty cross-Friesian dairy cows with an average initial weight of $515 \mathrm{~kg}$ were used in the study. Care and handling of the animals and sampling procedures described herein were approved by the El-Nubaria Research Station of Animal Production Research Institute, Alexandria, Egypt.

The experiment was commenced in the dry period of cows, 6 weeks before calving, and after calving the first three months of lactation was taken into consideration. The cows were divided by an analogue method into two experimental groups (10 animals in each), and the number of lactation, milk yield for previous lactation, percentage proportion of HF genes and calving date were considered.

\subsection{Experimental Diets}

Table 1 shows the chemical composition of the diets during the experimental.

All cows were fed the same diets during the experiment: maize silage, concentrate fed mixture (CFM), rice straw (RS) and mineral-vitamin mixture. The amount of fodders was different in dry and lactation period. The daily rations of feed covered cows' maintenance requirement and requirement for the production of $10 \mathrm{~kg}$ milk. The cows producing more than $10 \mathrm{~kg}$ milk/day were additionally fed $1 \mathrm{~kg}$ of concentrate per each $2 \mathrm{~kg}$ of surplus milk. The concentrate was produced in a local feed mill belonging to an Experimental Station in Pawlowice according to our formula. The basal components were maize grains $(40 \%)$, soybean meal $(17 \%)$, wheat bran (25\%), cottonseed meal (8\%), molasses (6.5\%), salt $(1.5 \%)$ and limestone (2\%). The feeding groups were diversified with respect to the supplementary mineral mixtures which contained $\mathrm{Zn}, \mathrm{Cu}$, and $\mathrm{Mn}$ in sulphate or methionine forms given individually to the animals at a dose of 2 g/day/head: Group I-control Mineral-vitamin mixture contains $\left(15 \mathrm{mg} \mathrm{Zn}\right.$ as $\mathrm{ZnSo}_{4}, 20 \mathrm{mg} \mathrm{Mn}$ as $\mathrm{MnSO}_{4}, 10 \mathrm{mg} \mathrm{Cu}$ as $\mathrm{CuSO}_{4}$ ) in sulphate forms and 2500 IU of vitamin A, 900 IU of vitamin $\mathrm{D}_{3}$, and 5 IU of vitamin E. Group II-experimental Mineral-vitamin mixture contains (15 mg Zn as ZnMet, $20 \mathrm{mg}$ Mn as MnMet, 10 $\mathrm{mg} \mathrm{Cu}$ as $\mathrm{Cu}$ Met) in organic forms and 2500 IU of vitamin A, $900 \mathrm{IU}$ of vitamin $\mathrm{D}_{3}$, and $5 \mathrm{IU}$ of vitamin $\mathrm{E}$.

\subsection{Milk Collection and Analysis}

Milk samples were collected from each cow evening and
Table 1. Chemical composition and fiber fractions of concentrate fed mixture (CFM), rice straw (RS) and corn silage (CS) (\% on DM basis).

\begin{tabular}{cccc}
\hline Item & CFM & RS & Corn silage \\
\hline DM & 89.62 & 90.48 & 30.83 \\
OM & 94.83 & 87.95 & 91.54 \\
CP & 15.88 & 3.81 & 8.14 \\
CF & 7.84 & 38.22 & 24.83 \\
EE & 2.93 & 0.94 & 1.43 \\
NFE & 68.18 & 44.98 & 57.14 \\
Ash & 5.17 & 12.05 & 8.46 \\
NDF & 23.65 & 67.86 & 52.75 \\
ADF & 15.87 & 49.88 & 39.54 \\
ADL & 5.32 & 19.75 & 12.77 \\
Hemicellulose & 7.78 & 17.98 & 13.21 \\
Cellulose & 10.55 & 30.13 & 26.77 \\
\hline
\end{tabular}

morning for estimation of milk yield production by [13]. A sample of milk $(100 \mathrm{ml})$ was taken from two consecutive milking. Milk samples were chemically analyzed for total solid (TS), protein, fat and ash according to [13] while lactose was calculated by differences.

\subsection{Feces Collection and Analysis}

For the digestibility trials three adult male Barki sheep weighing approximately $52.50 \pm 2.00 \mathrm{~kg} \mathrm{BW}$, were housed in metabolic cages for each trial. Sheep were kept on the diets for a preliminary period of 21 days, and during the next 7-day total feces and urine were collected. Subsamples (20\%) of feces and urine were taken once daily and were frozen until analyses.

Fecal samples were dried at $60^{\circ} \mathrm{C}$ for $72 \mathrm{~h}$. Feed and fecal samples were ground through $1 \mathrm{~mm}$ screen on a Wiley mill grinder and the sample $(50 \mathrm{gm} / \mathrm{sample} /$ treatment/sheep) were composed for analysis. The samples of feed and feces were analyzed for crude protein (CP), crude fiber (CF), Ether extract (EE) and ash, while the urine sample output for each sheep was analyzed for nitrogen $(\mathrm{N})$ according to [14]. Values of the total digestible nutrients (TDN) were calculated according to the classic formula of [15] on a dry matter basis (DM).

\subsection{Rumen Liquid Collection and Analysis}

Rumen liquid samples taken at 0,3 and $6 \mathrm{~h}$ post feeding from three fistulated adult female Barki sheep weighing 
approximately $47.50 \pm 0.50 \mathrm{~kg}$ BW for each treatment, were analyzed immediately for $\mathrm{pH}$ using Orian 680 digital $\mathrm{pH}$ meter. Samples were strained through four layers of chesses cloth. For each sampling time, rumen fluid samples were preserved for ammonia nitrogen $\left(\mathrm{NH}_{3}-\mathrm{N}\right)$ determination by adding concentrated $\mathrm{H}_{2} \mathrm{SO}_{4}$ (3 drop per $5 \mathrm{ml}$ ). The concentration of $\mathrm{NH}_{3}-\mathrm{N}$ was determined by using magnesium oxide (MgO) as described by [13]. Total volatile fatty acid (VFA's) concentration was estimated by using steam distillation methods [15].

Cell walls were analyzed for neutral detergent fiber NDF, acid detergent fiber ADF and acid detergent lignin ADL using Tecator Fibretic system. Hemicellulose and cellulose were determined by difference between NDF and $\mathrm{ADF}$, and $\mathrm{ADF}$ and $\mathrm{ADL}$, respectively according to [16].

\subsection{Blood Collection and Analysis}

Blood samples were collected twice (once before the experimental beginning and the other once at the end of the experimental period, from all cows. Blood samples were obtained from the external jugular vein of the animals in the morning before access to feed and water. Plasma or serum were obtained by centrifugation of blood and were stored at $-20^{\circ} \mathrm{C}$ until used for analysis. Serum total protein (TP) was measured as described by the Biuret method according to [17]. Albumin (A) concentration was determined according to the method of [18]. Kidney function was evaluated by measuring blood urea using the colorimetric methods of [19] using commercial kits. Liver function was assessed by measuring the activities of aspartates aminotransferase (AST) and alanine aminotransferase (ALT) by method of [20].

\subsection{Statistical Analysis}

Means were calculated for all variables by cow within period. Data were analyzed using the mixed procedure of SAS (SAS, 1999). Period and cow were considered random effects; diet and cannulation effects were considered fixed. Estimation method was restricted maximum likelihood and the degrees of freedom method was Kenward-Roger [21]. Differences were tested using the PDIFF option in SAS [21]. Differences were declared significant at a $\mathrm{p}<0.05$; and trends were discussed at a $\mathrm{p}$ $<0.15$, unless stated otherwise.

\subsection{Aim of the Work}

Comparing the effect of feeding chelated minerals (Mn, $\mathrm{Cu}$ and $\mathrm{Zn}$ methionine complexes) and mixture of inorganic metals ( $\mathrm{Mn}, \mathrm{Cu}$ and $\mathrm{Zn}$ sulphate) on dairy cow productive, performance of milk and its components.

\section{Results and Discussion}

\subsection{Digestibility Coefficients, Nutritive Values and Nitrogen Utilization}

The data on intake, digestibility of different nutrients during metabolism trial and data of daily nitrogen intake, excretion and retention are presented in Table 2. The DMI was comparable $(\mathrm{p}<0.05)$ at 63.19 and 65.74 in inorganic and organic metals respectively. Digestibility of (DM, OM, CP, EE, NDF, hemicelluloses and cellulose) and total digestible nutrients (TDN and DCP) were significantly $(\mathrm{p}<0.05)$ higher in organic metal as compared to inorganic metal groups. supplementation of organic metal had a great effect on DMI as compared to inorganic metals (Table 2) contrary to our observation [22] reported a linear decrease in the DMI with the increasing concentration 20, 100 and $200 \mathrm{mg} / \mathrm{kg}$ DMI of $\mathrm{Zn}$ in the diet (having $70 \mathrm{mg} / \mathrm{kg}$ ) in beef steers. But it might be due to very high intake of organic Zn (being 90, 170 and 270 $\mathrm{mg} / \mathrm{kg}$ ) DM, respectively, in these animals. However, [23] did not find any effect on DMI in group calves, when level of organic Zn was increased from 26.21 to 85.67 $\mathrm{mg} / \mathrm{kg} \mathrm{DM}$ in their diet. Supplementation of Zn methionine to a basal diet containing more than $25 \mathrm{mg}$ $\mathrm{Zn} / \mathrm{kg} \mathrm{DM}$ had no effect on feed intake ewes. Feed intake was not significantly affected by Zn source or level during the experiment [24]. The feed intake tended to drop less in zinc methionine fed calves challenged with infectious Bovine Rhinotracheits (IBR) compared to $\mathrm{ZnO}$ fed calves. The calves fed $30 \mathrm{ppm}$ Zinc methionine had lower $(\mathrm{p}<0.05)$ feed intake compared to calves receiving $90 \mathrm{ppm}$ zinc. While in recovery from depressed feed intake due to IBR fever was slower for ZnO fed calves compared to calves fed zinc methionine. The differences among groups were significant [25]. Reported that newly arrived feedyard calves fed Fourplex (a feed additive from Zinpro Corporation that contains copper lysine, zinc methionine, manganese methionine and cobalt glucoheptonate) required fewer $(\mathrm{p}<0.05)$ medication days, but Fourplex did not improve average daily gain or feed intake, or reduce mortality [26,27]. They reported that copper lysine and copper sulfate performed the same [28]. Reported no effect of zinc methionine added to a basal diet when lamb average daily gain was measured. During gestation, zinc methionine fed ewes had higher $(p<0.05)$ feed intake, but no such effect was seen in lactation. Sheep fed zinc methionine ration as $15 \mathrm{mg} \mathrm{Zn}$ showed higher ( $<$ 0.05) apparent digestibility DM, OM, CP, CF, EE, NFE, NDF, ADF and nutritive values TDN and DCP than those fed other rations. These results are consistent with zinc methionine being absorbed more efficiently than $\mathrm{ZnSO}_{4}$ when supplemented at high concentration. Increased uptake of $\mathrm{Zn}$ from zinc methionine could be 
Table 2. Feed intake, digestion coefficients and nutritive values of experimental rations fed to sheep (mean $\pm \mathrm{SE}$ ).

\begin{tabular}{|c|c|c|}
\hline Item & $\begin{array}{l}\text { Inorganic metals } \\
\text { (Mn, Cu and } \mathrm{Zn}) \\
\text { sulphate }\end{array}$ & $\begin{array}{c}\text { Organic metals } \\
\text { (Mn, Cu and Zn) } \\
\text { methionine complexes }\end{array}$ \\
\hline \multicolumn{3}{|c|}{ DM intake, $g / h / d$} \\
\hline CFM & $672.15 \pm 22.65^{\mathrm{a}}$ & $656.45 \pm 15.77^{\mathrm{b}}$ \\
\hline Corn silage & $369.92 \pm 19.38^{\mathrm{b}}$ & $385.33 \pm 0.21 .84^{\mathrm{a}}$ \\
\hline Rice straw & $162.86 \pm 0.96^{\mathrm{b}}$ & $180.96 \pm 1.73^{\mathrm{a}}$ \\
\hline Total DMI, g & $1204.93 \pm 16.59^{\mathrm{b}}$ & $1222.74 \pm 23.14^{\mathrm{a}}$ \\
\hline $\mathrm{R}: \mathrm{C}$ ratio & $44: 56$ & $46: 54$ \\
\hline \multicolumn{3}{|c|}{ Digestion coefficients (\%) } \\
\hline DM & $63.19 \pm 0.38^{\mathrm{b}}$ & $65.74 \pm 0.25^{\mathrm{a}}$ \\
\hline $\mathrm{OM}$ & $63.73 \pm 0.42^{\mathrm{b}}$ & $66.20 \pm 0.34^{\mathrm{a}}$ \\
\hline $\mathrm{CP}$ & $57.83 \pm 0.28^{\mathrm{b}}$ & $60.20 \pm 0.24^{\mathrm{a}}$ \\
\hline $\mathrm{CF}$ & $55.47 \pm 0.39^{b}$ & $59.51 \pm 0.31^{\mathrm{a}}$ \\
\hline $\mathrm{EE}$ & $76.92 \pm 0.16^{\mathrm{b}}$ & $78.24 \pm 0.43^{\mathrm{a}}$ \\
\hline NFE & $66.69 \pm 0.47^{\mathrm{b}}$ & $68.84 \pm 0.22^{\mathrm{a}}$ \\
\hline $\mathrm{NDF}$ & $62.66 \pm 0.48^{\mathrm{b}}$ & $64.27 \pm 0.28^{\mathrm{a}}$ \\
\hline $\mathrm{ADF}$ & $57.97 \pm 0.27^{\mathrm{b}}$ & $60.28 \pm 0.37^{\mathrm{a}}$ \\
\hline ADL & $43.27 \pm 0.39^{b}$ & $47.29 \pm 0.24^{\mathrm{a}}$ \\
\hline Hemicellulose & $65.27 \pm 0.72^{\mathrm{b}}$ & $67.29 \pm 0.25^{\mathrm{a}}$ \\
\hline Cellulose & $67.28 \pm 0.22^{\mathrm{b}}$ & $69.23 \pm 0.38^{\mathrm{a}}$ \\
\hline \multicolumn{3}{|c|}{ Nutritive values (\%) } \\
\hline TDN & $61.31 \pm 0.46^{\mathrm{b}}$ & $63.56 \pm 0.26^{\mathrm{a}}$ \\
\hline DCP & $6.87 \pm 0.11^{\mathrm{b}}$ & $7.05 \pm 0.16^{\mathrm{a}}$ \\
\hline \multicolumn{3}{|c|}{ Nitrogen utilization (g/h/d) } \\
\hline N-Intake & $22.89 \pm 0.14$ & $23.20 \pm 0.32$ \\
\hline N-Absorbed (NA) & $13.24 \pm 0.29^{b}$ & $13.97 \pm 0.15^{\mathrm{a}}$ \\
\hline N-Retention (NR) & $4.61 \pm 0.17^{\mathrm{b}}$ & $6.79 \pm 0.23^{\mathrm{a}}$ \\
\hline NR \% of NI & $20.16 \pm 0.31^{\mathrm{b}}$ & $29.27 \pm 0.28^{\mathrm{a}}$ \\
\hline NR \% of NA & $34.85 \pm 0.47^{\mathrm{b}}$ & $48.62 \pm 0.36^{\mathrm{a}}$ \\
\hline
\end{tabular}

${ }^{\mathrm{ab}}$ Means within rows with different superscript are significantly differ $(\mathrm{p}<$ $0.05)$.

explained by zinc methionine interacting less than $\mathrm{ZnSO}_{4}$ with antagonists that form insoluble complexes. Alternatively, Zn from zinc methionine may have been associated with ligands that facilitated Zn uptake in the duodenum. Metal ions may be absorbed as part of metal peptide complex, thereby facilitated absorption of $\mathrm{Zn}$ via intestinal transport mechanisms distinct from inorganic zinc [29]. Data of nitrogen of organic metal was the highest (6.799), the mean that treatments improved nitrogen balance. There were reflected in better $(p<0.05)$ $\mathrm{N}$-utilization of the ration fed to sheep. It may be possible for metal ions to be transported into the intestinal mucosa as part of metal peptide complexes via mechanism distinct from ionic Zn [30]. [31] reported increased $\mathrm{N}$-retention with the increasing dietary concentration of $\mathrm{Zn}$ from 40 to $70 \mathrm{mg} / \mathrm{kg}$ DM in dry cows. But contrary to our finding [32-35], did not find any effect of Zn supplementation on $\mathrm{N}$ metabolism. It appears that there is a three should level of $\mathrm{Zn}$ needed in the diet for optimum $\mathrm{N}$ metabolism and supplementation above which has no further impact. The basal diet in the present experiment contained $15 \mathrm{mg}$ as zinc methionine, $20 \mathrm{mg}$ manganese as manganese methionine, $10 \mathrm{mg}$ copper as copper methionine in organic forms, which might have been sufficient for optimum nitrogen metabolism in the cattle.

\subsection{Rumen Liquid Collection and Analysis}

Resulted of Table 3 indicated that rumen liquor $\mathrm{pH}$ values did not significantly differ among treatments. Organic metals sources tested in the present study showed different degrees acidity. When saturated solutions were prepared in deionized water, the $\mathrm{pH}$ of the solutions decreased. The consistency of $\mathrm{pH}$ readings can be used as one criterion to test product uniformity from batch to batch [36]. The amount of organic metals that could be dissolved in deionized water varied than inorganic metals in the present experiment indicating different degrees of solubility. The $\mathrm{NH}_{3}-\mathrm{N}$ were significantly $(\mathrm{p}<0.05)$ higher in inorganic metals than organic metals. Sheep in organic metals treatment had higher $(\mathrm{p}<0.05)$ total VFA concentrations than those in the inorganic metals. Alternatively metals from organic source may have been taken up by ruminal microorganism to a greater extent, and this

Table 3. Rumen liquor parameters of sheep fed the experimental diets (mean $\pm \mathrm{SE}$ ).

\begin{tabular}{ccc}
\hline Item & $\begin{array}{c}\text { Inorganic metals } \\
\left(\begin{array}{c}\text { Mn, Cu and Zn) } \\
\text { sulphate }\end{array}\right.\end{array}$ & $\begin{array}{c}\text { Organic metals } \\
(\text { Mn, Cu and Zn) } \\
\text { methionine complexes }\end{array}$ \\
\hline $\mathrm{PH}$ & $6.57 \pm 0.11$ & $6.45 \pm 0.05$ \\
$\mathrm{NH}_{3}-\mathrm{N}(\mathrm{mg} / 100 \mathrm{ml})$ & $14.16 \pm 0.16^{\mathrm{b}}$ & $13.32 \pm 0.23^{\mathrm{a}}$ \\
Total VFA's ml equv/100ml & $8.28 \pm 0.27^{\mathrm{b}}$ & $10.98 \pm 0.11^{\mathrm{a}}$ \\
Rumen volumes (L) & $3.17 \pm 0.17^{\mathrm{b}}$ & $3.88 \pm 0.13^{\mathrm{a}}$ \\
$\begin{array}{c}\text { Rates of outflow (\% hr) } \\
\text { Microbial protein synthesis } \\
\text { (g/h/d) }\end{array}$ & $6.07 \pm 0.13^{\mathrm{b}}$ & $5.38 \pm 0.09^{\mathrm{c}}$ \\
\hline
\end{tabular}

${ }^{\mathrm{ab}}$ Means within rows with different superscripts are significantly different $(\mathrm{p}$ $<0.05)$. 
could explain the lower ruminal soluble metal concentration in steers fed inorganic metals. Steers supplemented with zinc proteinate [37] or a zinc polysaccharide [38] also had higher ruminal soluble zinc concentration than those receiving inorganic zinc oxide. The higher total VFA concentration observed in steers supplemented with zinc methionine or zinc glycine compared to animals fed the $\mathrm{ZnSO}_{4}$ treatments could relate to a slower rate of feed consumption or reduced rate of ruminal digestion. Extremely high concentrations $(1142 \mathrm{mgZn} / \mathrm{kg})$ of $\mathrm{ZnSO}_{4}$ have been shown to affect ruminal protozoa numbers and degradation of feed protein [39]. high dietary concentrations (250 - $1142 \mathrm{mgZn} / \mathrm{kg}$ ) of organic Zn have also increased molar proportion of propionate [40]. The effect of more physiological additions of $\mathrm{Zn}$ on ruminal fermentation has received little attention data of rumen volumes, rates of outflows and microbial protein synthesis are presented in Table 3 . The differences among groups were significant. The organic metals rations were higher ( $\mathrm{p}<0.05$ ) values of rumen volumes and microbial protein synthesis than inorganic metals, while the both of organic metals were the lower $(p<0.05)$ values of rates of out flow than inorganic metals. Ruminal microbial protein synthesis depends on supply of adequate amounts and type of carbohydrates (CHO) as an energy source for the synthesis of peptide bonds [41]. Synthetic amino acids or amino acids precursor (Methyl Hydroxy Analogue: MHA) are also used as ligands in chelating trace minerals. The definitive advantage of MHA is that it is nondegraded in rumen as there is no nitrogen atom in its chemical structure and hence rumen microbes do not recognize it as a source for microbial protein synthesis escapes the rumen degradation. Moreover, the molecular size of MHA chelated is below 400 Dalton which facilitated its efficient absorption through intestine.

\subsection{Milk Yields and Milk Composition}

Data concerning milk yield and its composition are presented in Table 4. The milk yield and fat corrected milk (FCM) were significantly increased $(p<0.05)$ for the organic metals ration compared with inorganic metals ration. The average daily milk yields were increased by $11.10 \%$ in organic metals ration than inorganic metals. However, improving nutrients composition, its digestibility and the feeding values of organic metals ration was reflect on the more \%FCM produced by dairy cattle fed the ration which had about $12.75 \%$ more $4 \%$ FCM than the inorganic metals. In addition to about $7 \%$ and $7 \%$ more protein and fat produced, respectively. Similarly, in the group of animals receiving methochelated bestmingold in mid and late stage of lactation also showed an increase in milk fat percentage by $0.2 \%$ which is highly
Table 4. Milk yields and milk composition of lactating cows fed on experimental rations (mean $\pm \mathrm{SE}$ ).

\begin{tabular}{ccc}
\hline Item & $\begin{array}{c}\text { Inorganic metals } \\
(\text { Mn, Cu and Zn) } \\
\text { sulphate }\end{array}$ & $\begin{array}{c}\text { Organic metals } \\
(\text { Mn, Cu and Zn) } \\
\text { methionine complexes }\end{array}$ \\
\hline Milk yields, kg/d & $13.78 \pm 1.28^{\mathrm{b}}$ & $15.31 \pm 1.65^{\mathrm{a}}$ \\
$4 \% \mathrm{FCM}^{*}$ & $13.01 \pm 0.43^{\mathrm{b}}$ & $14.67 \pm 0.34^{\mathrm{a}}$ \\
Fat & $0.50 \pm 0.06^{\mathrm{b}}$ & $0.57 \pm 0.04^{\mathrm{a}}$ \\
Protein & $0.44 \pm 0.03^{\mathrm{b}}$ & $0.51 \pm 0.02^{\mathrm{a}}$ \\
& Milk composition (\%) & \\
Total solids & $11.47 \pm 0.54^{\mathrm{b}}$ & $11.85 \pm 0.46^{\mathrm{a}}$ \\
Solids not fat & $7.85 \pm 0.25^{\mathrm{b}}$ & $8.12 \pm 0.42^{\mathrm{a}}$ \\
Fat & $3.62 \pm 0.28^{\mathrm{b}}$ & $3.73 \pm 0.26^{\mathrm{a}}$ \\
Protein & $3.18 \pm 0.16^{\mathrm{b}}$ & $3.31 \pm 0.12^{\mathrm{a}}$ \\
Lactose & $3.54 \pm 0.16^{\mathrm{b}}$ & $3.77 \pm 0.13^{\mathrm{a}}$ \\
Ash & $1.13 \pm 0.06^{\mathrm{a}}$ & $1.04 \pm 0.03^{\mathrm{b}}$ \\
\hline
\end{tabular}

${ }^{\mathrm{ab}}$ Means within rows with different superscript are significantly differ $(\mathrm{p}<$ $0.05)$; 4 \% FCM was calculated as: $0.4 \times$ milk yield $(\mathrm{kg})+15 \times$ fat yield $(\mathrm{kg})$ (Overmann and Fanmann, 1926).

significant compared to that in inorganic mineral treated group of animals $(0.08 \%)$. It has been suggested that organic minerals have an increased bioavailability, resulted in an increased absorption in the gastrointestinal tract [42]. This may lead to an improvement in performance or health or may reduce the level of mineral supplementation required in the diet [43] who reported an increased milk production in animals receiving diets containing organically complexed minerals and a mixture of inorganic and organically complexed minerals. The above results are thus in agreement to the researchers that feeding of organic minerals improves milk yield and performance of dairy cows. Improvement in milk production and component can be partially attributed to improved udder health and reduction of sometic cell count. From previous study [44] reported that sometic cell count was reduced by addition of $\mathrm{Zn}$ methionine complex to the diet, this refer to that $\mathrm{Zn}$ methionine plays integral role in immune function by activating T-lymphocyte responsiveness, thus impacting the effectiveness of somatic cells within the mammary gland.

\subsection{Blood Biochemical and Serum Constituents}

The average values of some blood constituents in the blood of dairy cattle consuming the different experimental rations are presented in Table 5. No significant differences were observed among groups concerning the entire blood constituent. Moreover, they were within the 
Table 5. Blood serum parameters of lactating cows fed experimental ration (mean $\pm \mathrm{SE}$ ).

\begin{tabular}{ccc}
\hline Item & $\begin{array}{c}\text { Inorganic metals } \\
(\mathrm{Mn}, \mathrm{Cu} \text { and } \mathrm{Zn}) \\
\text { sulphate }\end{array}$ & $\begin{array}{c}\text { Organic metals } \\
(\mathrm{Mn}, \mathrm{Cu} \text { and Zn }) \\
\text { methionine complexes }\end{array}$ \\
\hline Glucose mg/dl & $88.78 \pm 1.86$ & $90.14 \pm 0.95$ \\
TP g/dl & $8.28 \pm 0.23$ & $8.42 \pm 0.39$ \\
Albumin g/dl & $4.88 \pm 0.11$ & $4.64 \pm 0.22$ \\
Globulin g/dl & $3.40 \pm 0.36$ & $3.78 \pm 0.45$ \\
Urea mg/dl & $39.22 \pm 0.95$ & $37.07 \pm 1.35$ \\
AST U/L & $44.75 \pm 1.37$ & $44.18 \pm 1.33$ \\
ALT U/L & $13.43 \pm 0.67$ & $13.65 \pm 0.79$ \\
\hline
\end{tabular}

There is no significant differences within either rows.

normal average as described by [45]. [46] compared zinc methionine, zinc sulfate and zinc oxide in 32 yearling cattle and detecting no difference on all parameters measured, which included serum, liver, pancreas, kidney, bone, bone marrow, hair and muscle, metallothionine levels likewise were not different. Working with calves, [47] reported increased ( $p<0.05$ ) expression of histocompatibility complex class for copper lysine fed animals compared to controls fed copper sulfate. In a companion study, these same workers [48] related that copper lysine increased $(\mathrm{p}<0.05)$ plasma copper and monocyte phagocytic activity compared to control, but controls received only half as much copper as the copper lysine group (43 v 104 ppm).

\section{REFERENCES}

[1] P. R. Henry, C. B. Ammerman and R. C. Littell, "Relative Bioavailability of Manganese from Manganese in Methionine Complex and Inorganic Sources for Ruminants," Journal of Dairy Science, Vol. 75, 1992, pp. 3473-3478. doi:10.3168/jds.S0022-0302(92)78123-5

[2] J. D. Ward, J. W. Spears and E. B. Kegley, "Bioavailability of Copper Proteinate and Copper Carbonate Relative to Copper Sulfate in Cattle,” Journal of Dairy Science, Vol. 79, No. 1, 1996, pp. 127-132. doi:10.3168/jds.S0022-0302(96)76343-9

[3] J. D. Bailey, R. P. Ansotegui, J. A. Paterson, C. K. Swenson and A. B. Johnson, "Effects of Supplementing Combinations of Inorganic and Complexed Copper on Performance and Liver Mineral Status of Beef Heifers Consuming Antagonists,” Journal of Animal Science, Vol. 79, No. 11, 2001, pp. 2926-2934.

[4] Z. Zin, D. F. Waterman, R. W. Neinken and R. J. Harmon, "Copper Status and Requirement during the Dry Period and Early Lactation in Multiparous Holstein Cows," Journal of Dairy Science, Vol. 76, No. 9, 1993, pp. 27112716. doi:10.3168/jds.S0022-0302(93)77607-9
[5] H. J. Weil, L. H. Haverland and D. W. Cassard, "Potassium Requirement of Dairy Calves," Journal of Dairy Science, Vol. 71, No. 7, 1988, pp. 1868-1872. doi:10.3168/jds.S0022-0302(88)79756-8

[6] J. E. Manspeaker, M. G. Robl, G. H. Edwards and L. W. Douglass, "Chelated Minerals: Their Role in Bovine Fertility,” Veterinary Medicine, Vol. 82, 1987, pp. 951-956.

[7] N. Ayalon, “A Review of Embryonic Mortality in Cattle," Journal of Reproduction and Fertility, Vol. 54, 1978, pp. 483-493. doi:10.1530/jrf.0.0540483

[8] J. E. Manspeaker, M. G. Robl and G. H. Edwards, "Prevention of Early Embryonic Mortality in Bovine Fed Metalosates," Proceedings of the 4th International Symposium of Veterinary Laboratory Diagnosticians, Amsterdam, 2-6 June 1986.

[9] A. Bonomi, A. Quarantelli, A. Sabbioni and P. Superchi. "The Chelated Trace Elements in the Feeding of Dairy Cows,” Progresso Vets, Vol. 41, 1986, pp. 673-682.

[10] H. D. Ashmead and R. Samford, "Effects of Metal Amino Acid Chelates or Inorganic Minerals on Three Successive Lactations in Dairy Cows," International Journal of Applied Research in Veterinary Medicine, Vol. 2, No. 3, 2004, pp. 181-188.

[11] J. W. Spears, "Zinc Methionine for Ruminants: Relative Bioavailability of Zinc in Lambs and Effects of Growth and Performance of Growing Heifers,” Journal of Animal Science, Vol. 67, 1989, pp. 835-843.

[12] G. P. Lardy, M. S. Kerley and J. A. Paterson, "Retention of Chelated Metal Proteinates by Lambs," Journal of Animal Science, Vol. 70, Suppl. 1, 1992.

[13] AOAC, “Official Methods of Analysis," 17th Edition, Association of Official Analytical Chemists, Arlington, 2005.

[14] L. A. Maynard, U. K. Loosli, H. F. Hintz and R. G. Warner, “Animal Nutrition," 7th Edition, McGraw Hill Book Co., New York, 1978.

[15] C. I. Warner, "Production of Volatile Fatty Acids in the Rumen Methods of Measurement,” Nutrition Abstracts \& Reviews, Vol. 34, 1964, pp. 339-352.

[16] P. J. Van Soest, "Nutritional Ecology of the Ruminant," Vol. 112, O and B Books Inc., Corvallis, 1982, pp. 126127.

[17] R. J. Henry, D. C. Cannon and J. W. Winkelman, "Clinical Chemistry: Principles and Techniques,” 11th Edition, Happer and Row Publishers, New York, 1974, p. 1629.

[18] B. T. Doumas, W. A. Waston and H. G. Biggs, “Albumin Standards and the Measurements of Serum Albumin with Bromocresol Green,” Clinica Chimica Acta, Vol. 31, No. 1, 1977, pp. 87-96. doi:10.1016/0009-8981(71)90365-2

[19] J. B. Henry and S. D. Todd, "Clinical Diagnosis and Measurement by Laboratory Methods,” 16th Edition, W. B. Saunders and Co., Phliadephia, 1974, p. 260.

[20] S. Reitman and S. A. Frankel, "Colorimetric Method of Determination of Serum Glutamic Oxaloacetic and Glutamic Pyrovic Transaminase," American Journal of Clinical Pathology, Vol. 28, 1957, pp. 56-63. 
[21] SAS Institute Inc., "SAS User’s Guide," SAS Institute Inc., Cary, 1999.

[22] K. J. Malcolm-Callis, G. C. Duff, S. A. Gunter, E. B. Kegley and D. A. Vermeire, "Effects of Supplemental Zinc Concentration and Source on Performance, Carcass Characteristics and Serum Values in Finishing Beef Steers,” Journal of Animal Science, Vol. 78, No. 11, 2000, pp. 2801-2808.

[23] S. A. Khan, "Interaction of Copper and Zinc and Its Influence on the Metabolism of Major Nutrients in Growing Calves,” PhD Thesis, Aligarh Muslim University, Aligarh, 1978.

[24] N. K. Chirase, D. P. Hutchenson and G. B. Thompson, "Feed Intake, Rectal Temperature, and Serum Mineral Concentration of Feedlot Cattle Fed Zinc Oxide or Zinc Methionine and Challenged with IBR Virus,” Journal of Animal Science, Vol. 69, 1991, pp. 4137-4145.

[25] F. K. Brazle and G. Stokka, "Effect of Four Trace Mineral Elements on Gain and Health of Newly Arrived Calves,” The Professional Animal Scientist, Vol. 12, 1995, pp. 50-55.

[26] E. B. Kegley and J. W. Spears, "Bioavailability of Feed Grade Copper Sources (Oxide, Sulfate or Lysine) for Growing Cattle," Journal of Animal Science, Vol. 72, 1994, pp. 2728-2734.

[27] E. B. Kegley and J. W. Spears, "Immune Response and Perfomance of Sheep Fed Supplemental Zinc as Zinc Oxide or Zinc Methioine,” Journal of Animal Science, Vol. 72, Suppl. 1, 1994, p. 132.

[28] P. G. Hatfield, G. D. Snowder, W. A. Head, H. A. Glimp and T. Besser, "The Effect of Zinc Methionine and Level of Protein during Late Gestation and Early Lactation on Ewes Rearing either Single or Twin Lambs," Journal of Animal Science, Vol. 71, Suppl. 1, 1993, p. 292.

[29] A. A. Hassan1, Gh. M. El Ashry and S. M. Soliman, "Effect of Supplementation of Chelated Zinc on Milk Production in Ewes," Food and Nutrition Sciences, Vol. 2, No. 7, 2011, pp. 706-713. doi:10.4236/fns.2011.27097

[30] H. D. Ashmead, D. J. Graff and H. H. Ashmead, “A Secondary Intestinal Pathway for Absorption of DipepTide-Like Amino Acid Chelates,” Springfield, 1985, pp. 113-123

[31] S. Kinal, J. Press, K. Gediga and G. Ciesla, “Absorption of Zinc and Copper in Dry Cows," Proceedings of the 8th Symposium Microelement in Agriculture, Vol. 434, 1996, pp. 723-727.

[32] O. M. S. C. Moreiro, "Study on Zinc Supplementation in a Basal Diet for Ruminants,” World Review of Animal Production, Vol. 26, No. 1, 1991, pp. 77-80.

[33] N. A. Kumar, V. Kapoor and V. K. Paliwal, "Effect of Zinc Supplementation in Conventional Diets on Nutrient Digestibility, Growth and Nitrogen Balance in Kids," Annals Agriculture Biology Research, Vol. 7, 2002, pp. 201-206.

[34] S. E. Jadhav, "Effect of Different Levels and Sources of Zinc Supplementation on Growth, Nutrient Utilization, Rumen Fermentation, Blood Biochemical and Immune
Response in Male Buffalo Calves,” PhD Thesis, Indian Veterinary Research Institute, Izatnagar, 2005.

[35] G. P. Mandal, R. S. Dass, D. P. Isore, A. K. Garg and G. C. Ram, "Effect of Zinc Supplementation from Two Sources on Growth, Nutrient Utilization and Immune Response in Male Crossbred Cattle (Bos indicus $\times$ Bostaurus) Bulls," Animal Feed Science and Technology, Vol. 138, 2007, pp. 1-12.

doi:10.1016/j.anifeedsci.2006.09.014

[36] F. T. Gressley, "Zinc, Copper, Manganese, and Selenium in Dairy Cattle Rations," Proceedings of the 7th Annual Mid-Atlantic Nutrition Conference, University of Maryland, College Park, 2009.

[37] J. W. Spears and E. B. Kegley, "Effect of Zinc Source (Zinc Oxide vs Zinc Proteinate) and Level on Performance, Carcass Characteristics, and Immune Response of Growing and Finishing Steers,” Journal of Animal Science, Vol. 80, No. 10, 2002, pp. 2747-2752.

[38] K. D. Wennedy, W. M. Craig and L. L. Southern, "Ruminal Distribution of Zinc in Steers Fed a Polysaccharide-Zinc Complex or Zinc Oxide,” Journal of Animal Science, Vol. 71, No. 5, 1993, pp. 1281-1287.

[39] M. A. Froetschel, A. C. Martin, H. E. Amos and J. J. Evans, "Effects of Zinc Sulfate Concentration and Feeding Frequency on Ruminal Protozoal Numbers, Fermentation Patterns and Amino Acid Passage in Steers," Journal of Animal Science, Vol. 68, No. 9, 1990, pp. 2874-2884.

[40] H. M. Arelovich, F. N. Owens, G. W. Horn and J. A. Vizcarra, "Effects of Supplemental Zinc and Manganese on Ruminal Fermentation, Forage Intake, and Digestibility by Cattle Fed Prairie Hay and Urea," Journal of Animal Science, Vol. 78, No. 11, 2000, pp. 2972-2979.

[41] A. Bach, S. Calsamiglia and M. D. Stern, "Nitrogen Metabolism in the Rumen,” Journal of Dairy Science, Vol. 88, 2005, pp. E9-E21. doi:10.3168/jds.S0022-0302(05)73133-7

[42] J. W. Spears, "Organic Trace Minerals in Ruminant Nutrition,” Animal Feed Science and Technology, Vol. 58, No. 1, 1996, pp. 151-163. doi:10.1016/0377-8401(95)00881-0

[43] J. E. Noeek, M. T. Socha and D. J. Tomlinson, “The Effect of Trace Mineral Fortification Level and Source on Performance of Dairy Cattle,” Journal of Dairy Science, Vol. 89, No. 7, 2006, pp. 2679-2693. doi:10.3168/jds.S0022-0302(06)72344-X

[44] S. Sobhinard, D. Carlson and R. B. Koshani, "Effect of Zinc Methionine or Zinc Sulphate Supplementation on Milk Production and Composition of Milk in Lacting Daity Cows," Biological Trace Element Research, Vol. 136, No. 10, 2010, pp. 48-45. doi:10.1007/s12011-009-8526-3

[45] M. S. Stanek, W. FlorekRydzik and I. Rusiecka, "Effect of Energy Feeds in Diets for Sheep on Nutrient Digestibility and Rumen Digestion Process," Acta Academiae Agriculture ac Technicae Olstenesis, Vol. 37, 1992, pp. 3-11.

[46] L. X. Rojas, L. R. McDowell, R. J. Cousins, F. G. Martin, 
N. S. Wilkinson and A. B. Johnson, "Relative Bioavail of Two Organic and Two Inorganic Zinc Sources Fed to Sheep,” Journal of Animal Science, Vol. 72, Suppl. 1, 1994, p. 131.

[47] K. E. Saker, W. S. Swecker and D. E. Eversole, "Bovine Monocyte Major Histocompatability Complex Class II Expression of Copper Supplemented Beef Calves to Vac- cination,” Journal of Animal Science, Vol. 72, Suppl. 1, 1994, p. 359.

[48] K. E. Saker, W. S. Swecker and D. E. Eversole, "Effect of Copper Suplementation and Vaccination on Cellular Immune Response in Growing Beef Calves," Journal of Animal Science, Vol. 72, Suppl. 1, 1994, p. 131. 